\title{
AZ 1956-OS KÖZIGAZGATÁSI TERÜLETBEOSZTÁSI REFORMTERV FÖLDRAJZI KÉRDÉSEI
}

\section{HAJDÜ ZOLTÁN}

Az 1956-os területrendezési reformterv problematikája sokféle szempontból vizsgálható. Külön elemzést igényelnének a köztörténeti, politikai, közigazgatás-politikai, gazdaságpolitikai, párttörténeti, káderpolitikai és elmélettörténeti összefüggései. Az eddig megjelent értékelések egy része visszaemlékezés jellegứ momentumokat tartalmaz, a szerzók tevékeny kōzremúködői voltak a terv kidolgozásának (Beér 1962, Bora 1960, Markos 1962). Hencz A. irodalmi feldolgozások alapján követi nyomon az eseményeket, értékeli, összegzi a történteket (Hencz 1973).

Ebben a tanulmányban arra vállalkozom, hogy a számomra biztosított és engedélyezett levéltári források , a megjelent párthatározatok, a korabeli elemzések és napi sajtó alapján - korántsem végleges érvényư - összegzést adjak az 1956-os területrendezési reformfolyamatról. Az elemzés során kitûntetett figyelmet forditottam a területi, földrajzi összefuiggések értékelésére.

\section{Az 1956-os területrendezési terv közigazgatási-területszervezési elózményei}

Az 1956-os területrendezési terv közigazgatási-területszervezési elổzményei, problémái az 1949-50-es közigazgatási területi reformhoz kapcsolódnak. 1949-ben a reform kidolgozásakor a pártvezetésen belül is vita bontakozott ki a megyék és járások számát illetốen. Voltak, akik 7-9 megyében gondolkodtak, s készen volt egy 12 megyés tervezet is. Az 1950-es megye- és járásreform valóában csak területi korrekciókra szorítkozott (Katona - Szamel 1949, Kolozsváry - Szamel 1950). Az az alapelv érvényesült, hogy a lehetôségek szerint a korábbi területi struktúrát kell alapul venni, csak a kirívó területi aránytalanságokat kell megszúntetni. Az 1950-es reform , nem forgatta fel" az ország kỏzigazgatási területbeosztását, a stabilitás, az irányíthatóság, az ellenôrizhetóség befolyásolta a döntéseket. Az 1950-es reform eldöntötte a vitát, de korántsem zárta le végérvényesen.

A megyék területi reformjanak ügye már 1953-ban felvetódött. Gerố Ernố vezetésével egy bizottság alakult, amely áttekintette a megyék helyzetét ${ }^{2}$. A bizottság több változatban $(6,9$, 10 megyés) áttekintette a területi reformelképzeléseket s végül 1953. VI. 5-én állást foglalt a 10 megyés rendszer mellett. Az új területi beosztás 1955. I. 1-én lépett volna életbe, de a belsổ gazdasági, politikai nehézségek miatt levették a napirendról.

Összegezve megállapithatjuk, hogy az 1956-os terileti reformterv nem egy hirtelen, meggondolatlan politikai döntés eredménye - mint ahogy a legtöbbször értékelik -, hanem közvetlen folytatása az 1949-50-ben elhalasztott reformnak, s szervesen kapcsolódott az 1953-as, részletesen kidolgozott közigazgatási reformkoncepcióhoz. 


\section{A területrendezési terv politikai háttere}

1953 nyarán megkezdődött az MDP addigi politikai irányvonalának felülvizsgálata. A politikai irányvonal változása sok tekintetben és területen érintette az államigazgatust és az állami apparátust is. Megalakult a Racionalizálási Kormánybizottság (1953-1955), s megindult a mưködố struktúrák egyfajta kritikai áttekintése.

Az MDP 1954. május 24-e és május 30-a között megtartott III. kongresszusa napirendre túzte a szocializmus építésének, a népi demokrácia tíz esztendejének elemzését és a soron következó feladatok megvalósításának kérdéseit ${ }^{3}$. Rákosi Mátyás előadói beszédében érintette az államigazgatás problémáit, $s$ az eredmények bemutatásán túl kritikusan foglalkozott az államigazgatással: , ,Az államapparátus nagyon felduzzadt, költségessé vált, megnốtt benne a bürokratizmus, munkája számos esetben elszakadt az élettól és fóleg határozatok, utasítások gyártásában merül ki, melyek gyakran papíron maradnak. Mindez parancsolóan megköveteli, hogy olyan rendszabályokat foganatosítsunk, melyek az államigazgatást egyszerúbbé, olcsóbbá teszik, közelebb hozzák a dolgozó tömegekhez, csökkentik a túlzott centralizációt és harcolnak a bürokratizmus minden formája ellen"4.

Nagy Imre 1953. július 4-tól miniszterelnöki posztot töltött be, s ez a funkciója szinte determinálta arra, hogy , Az államigazgatás és a tanácsok feladatai” c. napirend elóadója legyen ${ }^{5}$. A helyi tanácsok létrehozását Nagy a magyar nép életének történelmi jelentôségư eseményeként értékelte, ugyanakkor érzékeltette - néha egészen szenvedélyesen - a tanácsrendszer felépítésében és fóleg múködésében jelentkezô hibákat, hiányosságokat. Megígérte a túlzott központosítás megszunntetését, az egész apparátus racionalizálását és csökkentését. A területi igazgatás vonatkozásában állást foglalt a járások és a járási tanácsok megerớsítése mellett, s ezt a , túlságosan felduzzadi megyei apparátus terhére" kívánta megvalósítani. Új alapokra akarta helyezni a helyi tanácsok gazdálkodását és a gazdálkodó szervezetekhez fưzổdố viszonyát.

Az 1954-ben kibontakozó jogalkotói folyamat a kongresszus határozataira támaszkodott, $\mathrm{s}$ a munka legfontosabb eredménye az 1954. szeptember 25-én életbelépett X. törvény, az ún. második tanácstörvény lett.

\section{A közigazgatási területi reformtervek kidolgozása}

1955 nyarától felerôsödött a közigazgatási területbeosztás problematikájával foglalkozók igénye az új területi reform elốkészítésére. A közigazgatási területbeosztással kapcsolatos szakirodalomban egyre nagyobb helyet kapott a közigazgatási területszervezéssel kapcsolatos kérdéskör, tudományos konferenciákat rendeztek ${ }^{6}$.

1955 ốszétớl kezdve szũk körben megkezdổoöt a közigazgatási reform elôkészítése. Az 1955 decemberi járásmegszúntetések (balatonfüredi, csongrádi, dunavecsei, kemecsei, nagylétai, ricsei, sárospataki, villányi) már kísérletnek, a területi reformra való felkészülésnek tekinthetôk. A 8 járás megszuintetésével akarták felmérni a lehetséges megtakarításokat. Úgy vélték, hogy a 8 járás felszámolásával 400 igazgatási dolgozó szabadul fel, csak a tanácsoknál 24 millió forintos megtakarítás jelentkezik, $\mathbf{4} 400$ hivatali helyiség használható fel más célokra. A reformterv késóbbi hatékonysági megtakarítási számításaikor a 8 járás àdatait vették alapul? 
Hajdú Zoltán: Az 1956-os közigazgatási területbeosztási reformterv földrajzi kérdései.

Tér és Társadalom, 3. 1989. 4. 43-61. p.
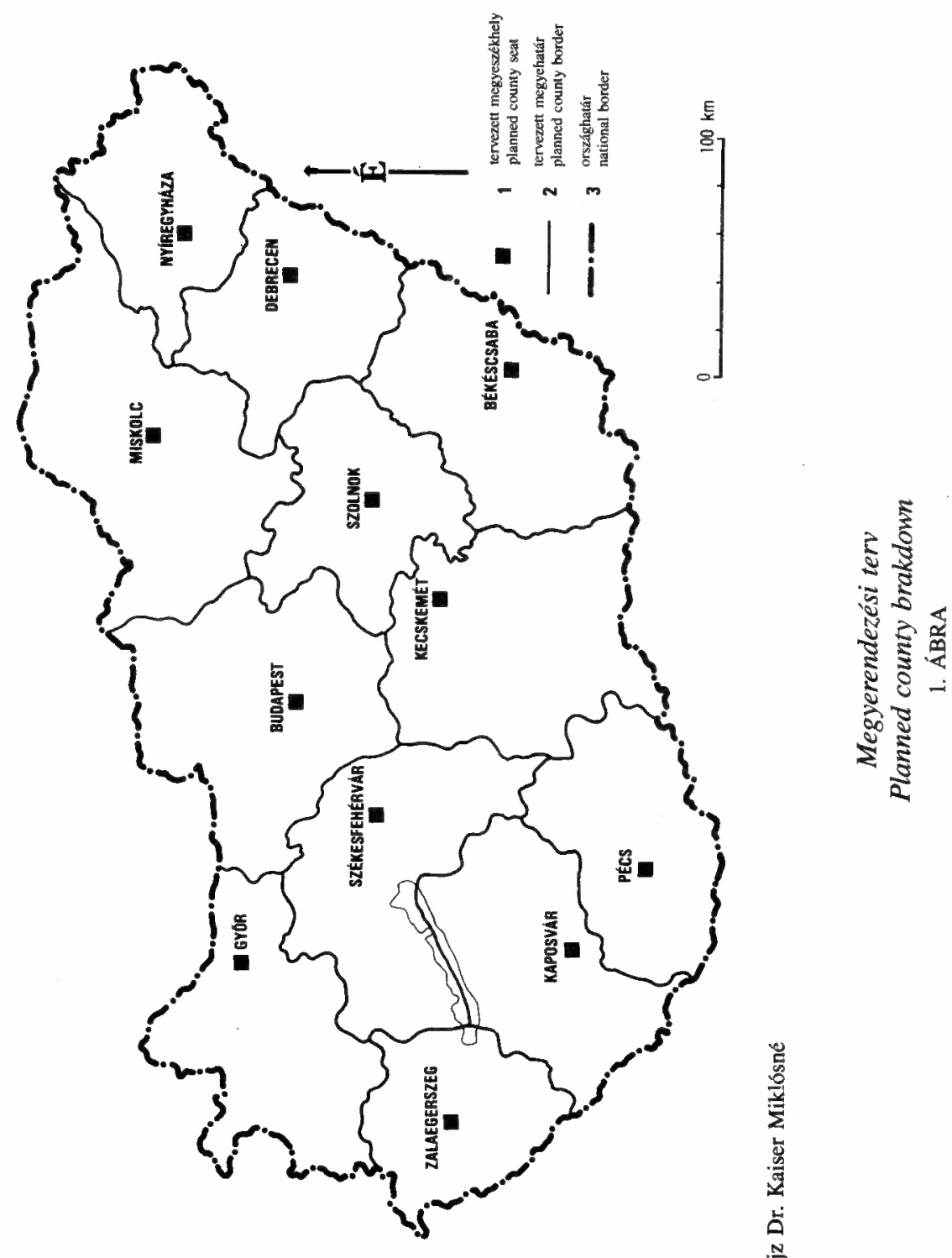

惫 
Apró Antal PB tag, miniszterelnök-helyettes vezetésével egy nagyon szükkörũ csoport abszolút titokban megkezdte a közigazgatási területi reform elókészítését. Az elsố tervek 1956 április elejére elkészültek ${ }^{8}$. A ,,megyeösszevonási terv” az MDP III. kongresszusának határozataiból kiindulva a megyék számának 12-re való csökkentését tủzte ki célul. A csökkentést a közigazgatási területbeosztás elaprózott jellegével, magas létszám- és költségigényével indokolták. A nagyobb megyék (Pest, Bács, Borsod) munkája azt bizonyítja, hogy a nagyobb terület és nagyobb népességszám nem akadálya a hatékony munkának. A kevesebb megyét jobban el lehet látni a megnövekedett feladatok ellátására alkalmas káderekkel. A megyékben feleslegessé váló, de vezetésre alkalmas emberekkel pedig a járási párt- és tanácsi apparátust lehetne megerốsíteni. A megyeszékhelyek számának csökkentése lehetôséget adna a megmaradó székhelyek gyorsabb ütemũ fejlesztésére, a kommunális ellátás javítására.

Figyelemre méltó a reformterv nemzetközi kitekintése: az utóbbi években a Szovjetúnió és a többi népi demokratikus állam is nagyobb összevonásokat hajtott végre a megyei szintũ területi struktúrájában. Mi rendelkezünk a legkisebb megyékkel, pedig közlekedési és telefonellátottságunk lényegesen jobb, mint pl. Romániáé vagy Lengyelországé.

Az új területi rend (1. ábra, 1. táblázat) az elổterjesztés szerint $50 \%$-os költségvetési megtakarítást eredményezne, s reálisabban tükrözné a területi kapcsolatokat. Az új megyehatárok kialakítása néhány járás megszũntetését is maga után vonja. A járáshatárok korrekcióját a megyerendezéssel egyidốben kell végrehajtani.

1. táblázat

A 12 megyés ország fổbb területi adatairól (elôzzetes számítások alapján)

\begin{tabular}{|c|c|c|c|c|c|c|}
\hline Megye & $\begin{array}{c}\text { Terület } \\
\text { ezer kh }\end{array}$ & $\begin{array}{l}\text { Lakosság } \\
\text { ezer fố }\end{array}$ & $\begin{array}{l}\text { Járások } \\
\text { száma }\end{array}$ & $\begin{array}{l}\text { Városok } \\
\text { száma }\end{array}$ & $\begin{array}{l}\text { Községek } \\
\text { száma }\end{array}$ & $\begin{array}{l}\text { Tanácsok } \\
\text { járási átlaga }\end{array}$ \\
\hline Baranya & 1180 & 470 & 9 & 4 & 323 & 36 \\
\hline Békés & 1410 & 610 & 8 & 6 & 110 & 14 \\
\hline Borsod & 1870 & 840 & 14 & 6 & 447 & 32 \\
\hline Fejêr & 1290 & 510 & 10 & 4 & 226 & 23 \\
\hline Gyôr & 1400 & 680 & 10 & 7 & 356 & 36 \\
\hline Hajdú & 1000 & 400 & 6 & 3 & 90 & 15 \\
\hline Kiskun & 1960 & 780 & 8 & 6 & 132 & 16 \\
\hline Pest & 1620 & 950 & 14 & 8 & 329 & 23 \\
\hline Somogy & 1300 & 460 & 9 & 1 & 286 & 32 \\
\hline Szabolcs & 1040 & 560 & 9 & 1 & 236 & 26 \\
\hline Szolnok & 1110 & 510 & 6 & 8 & 88 & 4 \\
\hline Zala & 1050 & 460 & 8 & 3 & 392 & 47 \\
\hline
\end{tabular}

Tehát az előkészítés elsố szakaszában részletekbemenôen kidolgozták a területi reform fốbt összetevôiit. Az indoklás sokféle elemet - néha ellentmondásokat is - hordozott. Egy kész koncepció, egy komplett ,,megyeösszevonási terv" indult vitára a legmagasabb fórumok felé 
Az MDP Politikai Bizottsága 1956. május 4-i ülésén vitatta meg a megyei beosztás reformjára vonatkozó tervezetet ${ }^{9}$. Határozatában kimondta, hogy elvileg elfogadja a megyék számának legalább 12-re, a járásoknak 100-ra, a budapesti kerületeknek pedig 14-re való csökkentését. A budapesti kerületek összevonására vonatkozó javaslatot június 30-ig, a megyék és járások összevonásával kapcsolatos konkrét terveket pedig november 1-ig kell kidolgozni. A PB határozata szerint a végrehajtás módjára vonatkozó konkrét javaslatot - a megfelelố szakemberek bevonásával - egy állami bizottság dolgozza ki. A területi reformmal párhuzamosan ki kell dolgozni a megyei és járási szervek önállóságát növelô és biztosító intézkedéseket is.

A PB határozat tovább megy, mint az eredeti elốterjesztés, a megyerendezést összekapcsolja egy szisztematikus járásrendezéssel és meghatározza a budapesti kerületek összevonásának irányait is. A keretjellegũ határozat lehetôséget adott a szakmai szempontok érvényesülésének is.

Gerố Ernố nem vett részt a PB ülésén, ezért utólag, írásban fejtette ki véleményét. Fớbb ellenvetései: Salgótarján nem tartozhat Borsodhoz, Hajdú és Szabolcs megyét össze kell vonni, Zalaegerszeg nem látszik megfelelố megyeszékhelynek. Véleménye szerint a megyék számát 9-10-re kell csökkenteni.

1956. május 18-án Rákosi Mátyás a Nemzeti Sportcsarnokban tartott pártaktíván mondott beszédében felvetette a megyék, járások és a budapesti kerületek számának csökkentési lehetốségeit. Nem ismertette az elfogadott keretszámokat, de egyértelmủen utalt arra, hogy lényegesen nagyobb területi egységekre van szükség ${ }^{10}$.

Rákosi bejelentése után megkezdổdött a reform nyilvános ideológiai, politikai és tudományos elókészítése ${ }^{11}$, növekedett a bizonytalanság a megyei és járási szervezetekben ${ }^{12}$. Megindul a különbözơ beadványok és reformtervek készítése. (P1. Dombóvár Községi Tanács VB elnöke és titkára levélben fordult a Központi Vezetôség Közigazgatási Osztályához, melyben megküldték saját reformtervezetüket. Két alapelvbốl indultak ki:

1. a közlekedési hálózat jellege,

2. az új székhelyeknek a megyék központjában kell lenniük.

Tervezetükben Celldömölk, Dombóvár, Hatvan, Kiskunhalas, Nyíregyháza, Szeghalom, Székesfehérvár lett csak megyeszékhely ${ }^{13}$.

A területi reform állami elókészítése a PB határozata után kezdôdött meg. Apró Antal a PB tagja, miniszterelnök-helyettes 1956. május 28-án elốterjesztéssel fordult a Minisztertanácshoz egy kormánybizottság megszervezése érdekében. A Területszervezési Kormánybizottság feladata a területi átszervezésekkel kapcsolatos elvi és gyakorlati kérdések irányítása kell hogy legyen. A Minisztertanács 1956. május 29-i határozatával létrehozta a Területszervezési Kormánybizottságot. A bizottság elnöke Apró Antal, titkára Varga András, tagjai: Bata István, Beér János, Berei Andor, Egri Gyula, Erdei Ferenc, Fekete Mihály, Matolcsi János, Olt Károly, Piros László, Pongrácz Kálmán, Szabó János lett. A területi reform kidolgozásának határidejét a Minisztertanács 1956. augusztus 31-ben határozta meg.

Megalakulásától kezdve a Területszervezési Kormánybizottság intenzív munkához fogott. Május 31-én elkészült munkaprogramja, mely tervezési és végrehajtási idốszakokra bontotta a feladatokat, meghatározta a munka menetrendjét. A Területszervezési Kormánybizottság két albizottságot alakított: Markos György vezetésével a megyerendezés alapelveit és kereteit, Erdei Ferenc irányításával a járásrendezési terveket dolgozták ki. Minden fớhatóság tárcamegbí- 
zottat delegált a Területszervezési Kormánybizottsághoz, akik a szakterületükön felvetổdố kérdésekkel, adatfeltárással és adatszolgáltatással segítették a munkát.

A szélesebb közvélemény a Szabad Nép június 24-i számából értesülhetett a Területszervezési Kormánybizottság tevékenységérổ. Apró Antal a bizonytalanságok eloszlatása érdekében részletesen foglalkozott a tervezett reform céljaival, összetevơivel ${ }^{14}$.

Az albizottságok alig egy hónap alatt elkészültek a munkával. A bizottság július 6-i ülésén már az új megyék kialakítása és elnevezése, a járások területszervezési kérdései szerepeltek a napirenden. A megyerendezés irányelvei c. elốterjesztés szerint a megyebeosztás elaprózott, drágítja az igazgatást, akadályozza a területi szervek teljesebb gazdasági önállóságának kibontakozását is. A megyék területének meghatározásakor az alábbi alapelvekbốl indultak ki:

1. A megyék területének kialakításakor törekedni kell arra, hogy az igazgatási beosztás lehetôleg egybeessen a gazdasági körzettel, az országon belül kialakult vagy kialakulóban lévớ földrajzi munkamegosztás alapegységeivel. A területi alapegységek kialakításakor nemcsak egyegy tényezốt, hanem a gazdasági, társadalmi, termelési stb. tényezốk összességét, az adott területnek a népgazdaság egészében betöltött szerepét kell figyelembe venni. Nemcsak a jelen helyzet mérlegelendô, hanem a jövô (10-15 év) fejlôdési perspektívája is.

2. Különös figyelmet kell fordítani a közlekedési és szállítási szempontokra, a központok és alközpontok megközelíthetôségére.

3. A gazdasági tényezốk mellett elsốrendũ fontosságúak a politikai szempontok (az ipari munkásság elhelyezkedése, súlya stb.), valamint a szociális és kulturális adottságok.

4. Az egyes alapegységek számának, területi nagyságának és lakosságszámának meghatározásakor messzemenốen figyelembe kell venni az eredményes igazgatási tevékenység, a vezetés és szervezés követelményeit.

5. A megyéknek lehetôleg egy-egy már meglévố és jelentốs fejlốdési lehetốségekkel rendelkezố nagyobb település - mint központ - körül kell kialakulniok. A nagyobb városokat közvetlenül a felsốbb vezetés irányítása alatt kell továbbra is múködtetni. A tervezéskor a körzetet és a kiemelt nagyobb várost egységként kell kezelni.

Az elốterjesztés 8 megye (Csongrád, Heves, Komárom, Nógrád, Somogy, Tolna, Vas, Veszprém) megszüntetésére és 11 új megye kialakítására tett javaslatot (2. ábra). Minden tervezett megyét röviden értelmez az alapelvek függvényében. Figyelemre méltó, hogy a javaslatban a korábbival ellentétben - Szeged és Nagykanizsa szerepel megyeszékhelyként.

Markos György a július 6-i ûlés elôtt levélben fordult Erdei Ferenchez, melyben kifejti a megyetervvel kapcsolatos észrevételeit, aggályait, amelyeket marxista tudományos lelkiismeretével összeegyeztethetetlennek tart. Markos szerint a bizottság elfogadta a megyerendezésre vonatkozó elổzetes irányelveit, ezzel szemben a megyék tagolására vonatkozó tényleges javaslat csak egészen elmosódottan tartalmazza azokat, praktikus és napi politikai célokat követve és opportunista módon alakítja ki a megyék határait. Legfontosabb ellenvéleménye, hogy Pest megyét nem kell óriássá tenni, amúgy is túlsúlyos a szerepe. A megye nem foglalhat mást magában, mint a fổvároshoz közvetlenül kapcsolódó városellátó jellegú mezôgazdasági területeket. Kérdéses számára Hajdú és Szabolcs-Szatmár külön tartása, a kaposvári járás Baranyához, a tapolcai Zala megyéhez csatolása is.

A járási területrendezés irányelvei $\mathrm{c}$. anyag 11 oldal terjedelmú, sok tekintetben átgondoltabb, koncepciózusabb, mint a megyerendezési. Erôteljesen érződik rajta a munkabizottság 
Hajdú Zoltán: Az 1956-os közigazgatási területbeosztási reformterv földrajzi kérdései.

Tér és Társadalom, 3. 1989. 4. 43-61. p.

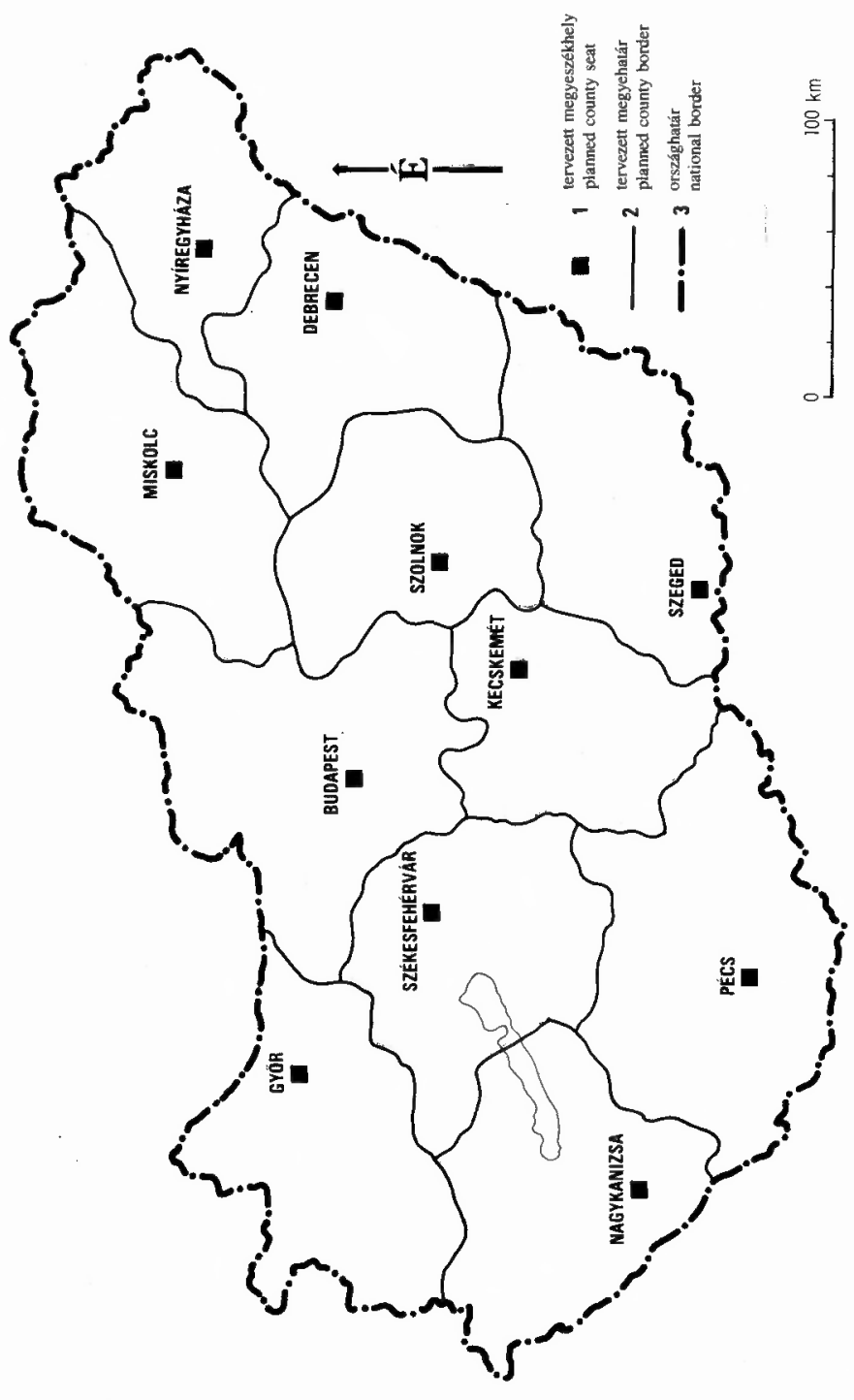

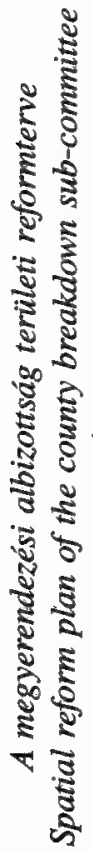


vezetôjének - Erdei Ferencnek - a hatása. Sokszínũen, nemzetközi összehasonlításban vizsgálja a magyar járásrendszer történeti, közigazgatási kérdéseit, külön kitér a városkörnyékiség, a községek város alá rendelésének problematikájára.

A járási területrendezés irányelveiként elfogadták:

1. A járások területe minél nagyobb mértékben essék egybe egy-egy összefüggô gazdasági körzettel, s hogy igazgatásuk magasabb színvonalonés nagymértékben önálló hatáskörrel szervezhetô legyen - a járások területét növelni kell. Olyan járási egységeket kell kialakítani, hogy a megyei igazgatási hatásköröket az elérhetô legnagyobb mértékben járási szintre lehessen levinni.

2. Figyelembe kell venni a városi központokat és azok kialakult vonzásterületét, a közöttük fennálló sokoldalú kapcsolatokat.

a) Legyen olyan központi város, amelyhez kiépült közlekedési hálózat köti a járás területét. Ahol ilyen kiépült központi város nincs és a terület nem tartozik közelebbi központ vonzásterületébe, ott a központtá fejlesztés szempontjából legfejlődôképesebb községet kell járási székhellyé kijelölni.

b) A járások, mint gazdasági körzetek, a helyi viszonyok szerint, egyaránt lehetnek egységes vagy egymást kiegészítô gazdasági területek, és nagymértékben figyelembe kell venni az e téren kialakult hagyományos viszonyokat, valamint a fejlesztés távlatait. Lehetốleg el kell kerülni az egységes termốtájak feldarabolását, kivéve, ha azok nagysága meghaladja egy járás méreteit.

3. A jelenlegi járási keretekbôl kell kiindulni és csak indokolt változtatásokat lehet végrehajtani olyan esetekben, amikor a jelenlegi határok nem felelnek meg a tényleges gazdasági összefüggéseknek, vagy nincs fejlődốképes központjuk, illetốleg túl kicsi egységek ahhoz, hogy megfelelő szintử járási igazgatási hatáskörrel legyenek felruházhatók.

4. A járások területrendezése során meg kell oldani a járások és a járási jogú városok ellentétét. Érvényesíteni kell azt az elvet, hogy minden olyan várost, amelyet valamilyen különleges indokból nem kell kiemelni a járás alól, a járási igazgatás alá kell rendelni. Számukra járás alá tartozó városi jogállást kell kialakítani. Így mintegy 120 járási szintủ területi egység lenne.

5. A területrendezés nem valósítható meg csupán az igazgatási határok megváltoztatásával. Elengedhetetlenül szükséges, hogy a területrendezéssel együtt néhány alapvetổ igazgatási kérdés is megoldást nyerjen.

a) Az új járások hatáskörét minisztertanácsi határozatban újból meg kell állapítani, figyelembe véve, hogy a megyei hatáskör döntố részét le kell adni a járásokhoz. A hatásköri rendezést úgy kell végrehajtani, hogy általános közigazgatási ügyekben a község és város legyen az elsőfokú hatóság, míg a járás irányító jogkört és a gazdasági irányítás tekintetében kiterjedt hatáskört, széles önállóságot kapjon.

b) A megyei jogú városok mellett a területrendezésrốl szóló törvényben új városi jogállást (járás alá rendelt város) kell létesíteni. Ezek önállósága a lehetôség szerint nagy legyen, viszont a járásba beépülnének, másodfokú hatóságuk a járási tanács és igazgatási szervei lennének.

c) ,,... szükséges, hogy újból életre hívjuk a városkörnyéki községeket. Az ilyen községeket 
Hajdú Zoltán: Az 1956-os közigazgatási területbeosztási reformterv földrajzi kérdései.

Tér és Társadalom, 3. 1989. 4. 43-61. p.
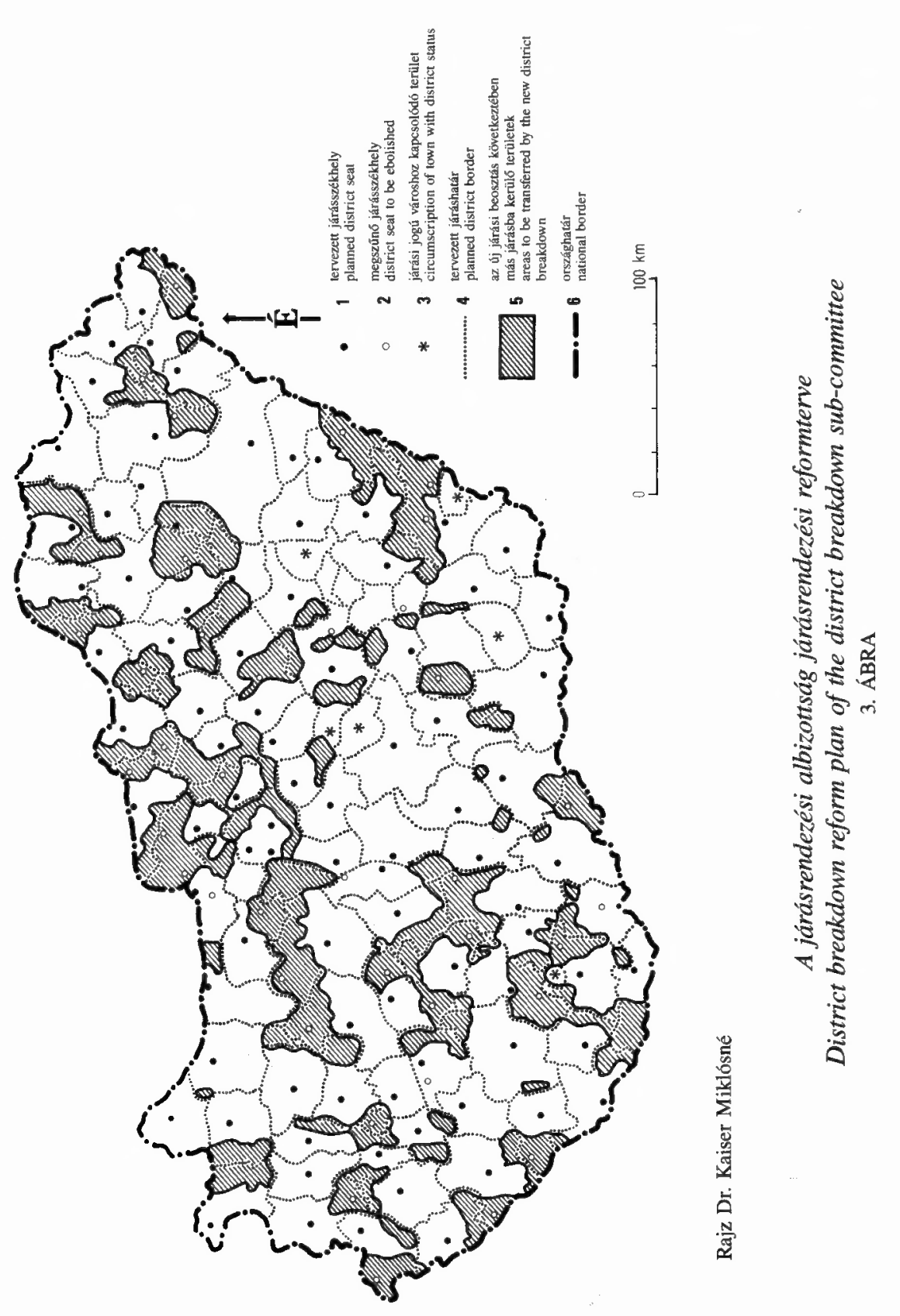
Hajdú Zoltán: Az 1956-os közigazgatási területbeosztási reformterv földrajzi kérdései.

Tér és Társadalom, 3. 1989. 4. 43-61. p.

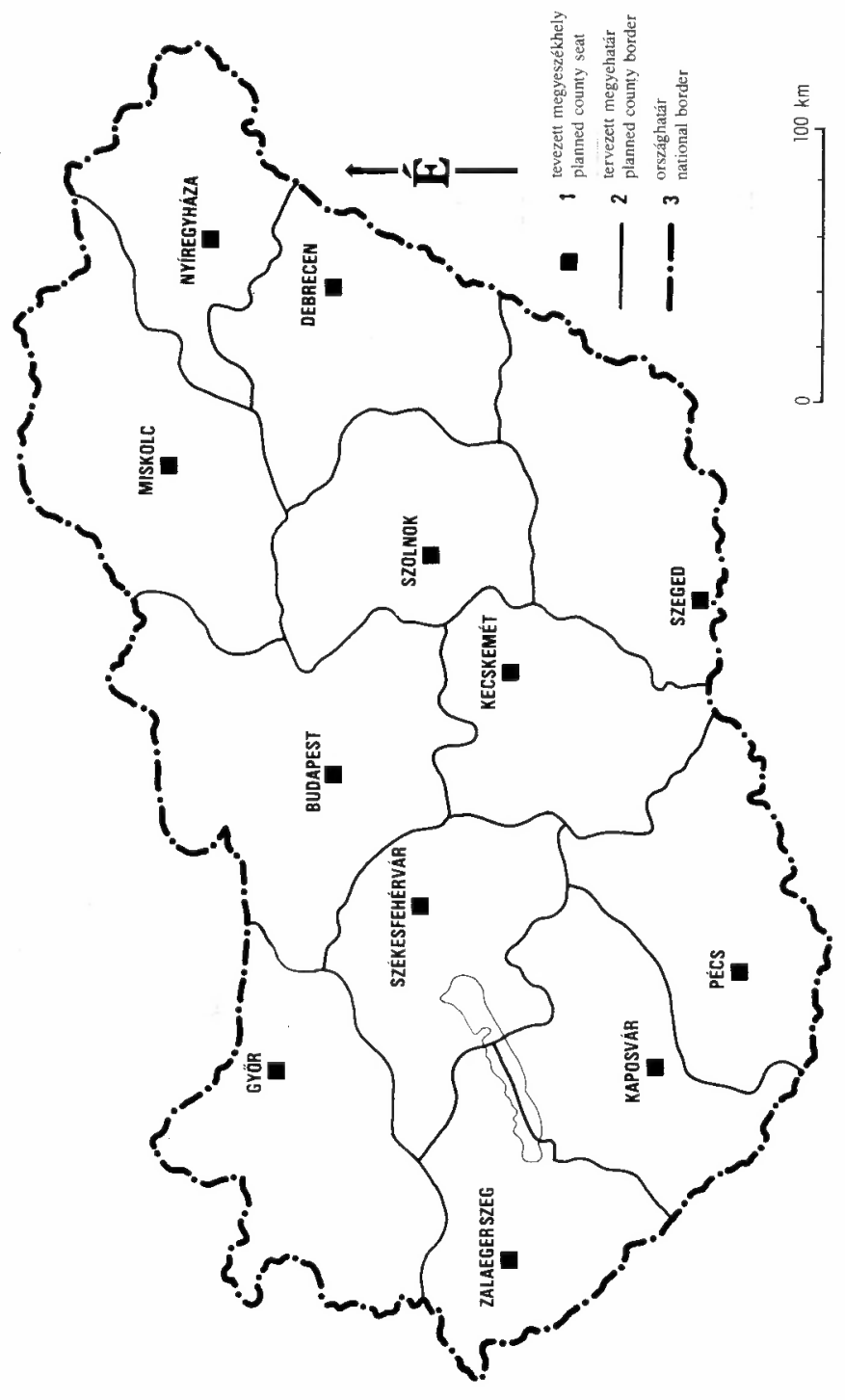

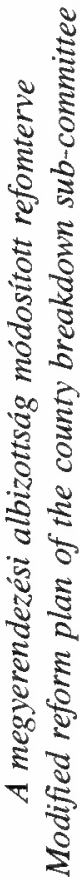

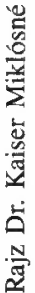


a város külsố területének kell tekinteni és községi tanács megtartásával, a járási hatáskör tekintetében a városi tanács alá kell helyezni".

6. A megyei és járási területrendezés elkerülhetetlenné teszi a községek és városok területrendezését és igazgatási hatáskörük fejlesztését, ezt legkésốbb 1957-ben végre kell hajtani.

Az elốterjesztés alternativ. Úgy itélik meg, hogy a járási területrendezés 2 változatban oldható meg. Az $A$ variánsban a járások száma 90 , a járási jogú városoké 58 , így összesen 148 járási szintú egység jönne létre az 5 megyei jogú város és a fôvváros mellett (3. ábra). A $B$ variáns szerint a járási jogú városok nagyobb része a járási tanács alá kerülne, ezzel párhuzamosan kialakulna a városkörnyéki területi rendszer. Ebben az esetben 92 járás, 18 járási jogú város maradna, így 113 járási szintũ egységgel, 5 megyei jogú várossal és a fôvárossal kellene számolni. A járás alá rendelt városok száma 50 körül alakulna. A $B$ változat szerint járási jogú város lenne: Baja, Békéscsaba, Eger, Kaposvár, Kecskemét, Nagykanizsa, Nyíregyháza, Ózd, Salgótarján, Sopron, Székesfehérvár, Szolnok, Szombathely, Sztálinváros, Tatabánya, Veszprém, Zalaegerszeg (Gyula, Hódmezôvásárhely, Karcag, Nagykôrös városkörnyéki községekkel is rendelkeznének) ${ }^{15}$.

A járásrendezési munkabizottság az elméleti és gyakorlati kérdések széleskörũ megvitatása után az $A$ változat mellett foglalt állást úgy, hogy javasolta néhány megoldás ismételt áttekintését.

A Területszervezési Kormánybizottság döntött arról, hogy a kidolgozott, megvitatott és jóváhagyott terveket (4. ábra) egyeztetni kell a minisztériális és megyei szervekkel. A megyékben öttagú bizottságot kellett létrehozni párt- és tanácsi vezetốkból, s július 15 -ig be kellett fejezni a véleményegyeztetést a megyét érintổ kérdésekben. A minisztériumokkal, országos hatáskörũ szervekkel július 31-ig kellett lezárni az egyeztetési munkát. S ezek után a Területszervezési Kormánybizottság a végleges, jóváhagyott tervezetet augusztus 15-én a Minisztertanács elé kívánta terjeszteni, s az országgyưlés szeptember 15-20 között vitatta volna meg és hagyta volna jóvá a területrendezési reformot.

Apró Antal július 11-én az MDP Központi Vezetôségéhez intézett beszámolójában összefoglalta a megyei, járási és budapesti kerületi beosztás ésszerüsítésével kapcsolatban végzett munkát. A Központi Vezetôség 1956. július 18-21-i ülésén a területrendezési kérdések is napirendre kerültek. Úgy ítélték meg, hogy a közigazgatási egységek átszervezése rosszkor került a felszínre, sok bizonytalanságot és zavart okozott. A kelló körültekintést szorgalmazták az ügyben (Szabó 1986), de a határozatok végül is állást foglaltak a területrendezés szükségessége, a munka folytatása mellett ${ }^{16}$.

A Területszervezési Kormánybizottság tagjai az elổre meghatározott ütemterv szerint megkezdték a tervezet egyeztetését a központi és a megyei szervekkel. A központi szervekkel szinte zökkenố nélkül folytak le az egyeztetések, sốt az egyes minisztériumok még további összevonásokat is javasoltak. Azokban a megyékben, amelyek a tervezet szerint megmaradnak, szintén nem került sor keményebb ütközésekre.

Az érdemi feszültségek a megszüntetésre ítélt megyékben jelentkeztek, általában élesen tiltakoztak a megszüntetés ellen. A tiltakozásnak többféle módja és szintje alakult ki: egyesek személyesen keresték fel Apró Antalt és így próbálták meggyổzni a terv elhibázott jellegérōl. Mások még magasabb helyen tiltakoztak, ill. kerestek pártfogót. Voltak olyan megyék, amelyek 
tudományos elemzéssel támasztották alá tiltakozásukat és indokolták a központi terv elhibázott jellegét, önálló terveket dolgoztak ki.

Különösen erôs tiltakozó mozgalom alakult ki Vas és Veszprém megyében. Az MDP Veszprém Megyei Bizottsága és a Veszprém Megyei Tanács Végrehajtó Bizottsága javaslattal fordult a Területszervezési Kormánybizottsághoz a Dunántúl területrendezését illetôen, különös figyelemmel a közép-dunántúli iparvidék és a Balaton egy területi egységbe való foglalásával, egy nagy területũ központi Veszprém megye kialakítása tárgyában. A 16 oldal és 1 ábra terjedelmü anyagban a veszprémiek vitatják, ill. cáfolják a vitára bocsátott tervet. Egy nagy, központi Veszprém megyét kell kialakítani és körülötte kell létrehozni a periférikus megyéket a Dunántúlon. Tervezetük szerint Veszprém megye lenne a Dunántúl legnagyobb megyéje (1.195.000 kh) körülötte Gyốr-Sopron, Vas-Zala, Somogy, Pest dunántúli része és Baranya alkotná a Dunántúl közigazgatási területét. Részletesen kidolgozták a tervezett nagy Veszprém megye járásbeosztásának tervét is.

Vas megye vezetése egy Szombathely székhelyú ,,egységes tájjellegú és gazdasági adottságú megye" kialakítására tett javaslatot. A megye felölelte volna az akkori Vas megye területét, Zalából a Pacsa-Rédics vonalig terjedố területeket, Gyớr-Sopronból a soproni és a kapuvári járást, Veszprém megyébốl a devecseri és a sümegi járásokat.

A Területszervezési Kormánybizottság kibôvített ülésére meghívták a javaslattevő megyék képviselőit is - érdemben foglalkoztak a javaslatokkal, pontról-pontra vitatták az érveket. Külön tárgyalták a Közép-Dunántúl és a Balaton igazgatásának kérdését. Megállapították, hogy a Közép-Dunántúl egy megyét képez a Területrendezési Kormánybizottság terve szerint is, de nem Veszprém, hanem Székesfehérvár székhellyel, amely minden tekintetben fejlettebb mint Veszprém. A Balaton egységes megyébe foglalása mindenképpen gondot jelent. Úgy foglaltak állást, hogy nem lehet egy megyébe szervezni, több központ kell a Balaton körül, azt azonban javasolták, hogy egy központi szervezetet kell létrehozni a Balaton kiemelt fejlesztésére.

Hasonló részletességgel vitatták meg a szombathelyi vezetés elốterjesztését is. A bizottság végül is hosszas és éles vita után elutasította a megyei javaslatokat.

A Politikai Bizottság augusztus 16-i ülésén ismét áttekintette az átszervezés munkálatait. Apró Antal feljegyzése szerint a PB ülés a 12-es felosztás mellett döntött, nem kell a további összevonásokat erôltetni. A PB állást foglalt amellett is, hogy Békés-Csongrád egyesített megye székhelye Hódmezôvásárhely maradjon. El kell készíteni a budapesti átszervezés tervét is, az egész anyagot együtt kell látni és tárgyalni. A Balaton fejlesztésére létre kell hozni egy tanácsot, vagy bizottságot, amely terveket készít és irányt szab a Balaton-környék fejlesztésének. Meg kell vizsgálni annak lehetôségét, hogy nem lenne-e jobb, ha Szombathely Zala megyéhez kerülne. Át kell tekinteni ismét a Tata-Dorog és a Baja problémát. Meg kell vizsgálni, hogy Pest megye nem túlzottan nagy-e, s nem kellene-e bizonyos részeket Szolnokhoz vagy Borosodhoz csatolni. Kérdésként teszi fel a PB: szükséges-e, hogy Bács megye rövid szakaszon határos legyen Jugoszláviával. Nem lenne-e jobb, ha csak két megyéhez tartozna az alföldi jugoszláv határ.

Folytatódtak a beadvány benyújtások és a küldöttségjárások. Cegléd tiltakozott az ellen, hogy elcsatolják Pest megyétốl. Minden kapcsolata és érdeke oda köti. A szegedi vezetés egy beadványcsomaggal fordult a Területrendezési Kormánybizottsághoz, amelyben követelte, hogy Szegedet nyilvánítsák megyeszékhellyé. Mindenre kiterjedóen indokolták ennek létjogosultsá- 
gát és egy országos megyebeosztási tervet is mellékeltek követeléseikhez. A beadvány hangneme roppant éles, megfogalmazásai kemények: "... egyszer beszéljünk már nyíltan erról - ... Szeged mostoha gyermeke a kormányzatnak. ..., " ... a szegedi dolgozók tehetnek-e arról, hogy Horthy innen indította el majd 40 éve az ellenforradalmat? Emiatt kell egy jobb sorsra érdemes várost büntetés alatt tartani? Szinte már fáj az a mellôzzés, amely Szeged dolgozóit lépten-nyomon éri". Követelték, hogy rehabilitálják Szegedet, mely a leginkább megszenvedte a Tito-ellenes hajszát. Ugyanakkor ,,Szegednek ... megyeszékhellyé történổ kijelölése egyenesen szimbóluma lehetne a két ország új viszonyának" ${ }^{17}$.

Apró Antal a tárcamegbízottakkal kivizsgáltatja a szegedi beadványban szereplố érveket és megállapítják, hogy azok minden tekintetben megfelelnek a valóságnak. Apró úgy véli, hogy a szegedieknek igazuk van, kéri Révai József véleményét az ügyrôl, mert úgy ítéli meg, hogy azt esetleg ismét a PB elé kellene vinni.

Augusztus végére a bizottságon belül tisztázódott a megyék és járások átszervezésének konkrét menete, tartalma, elkészültek a korrigált beosztások, befejezổdtek a kiegészítô vizsgálatok. Augusztus 28-án már elốterjesztést dolgoztak ki a területátszervezés idejére kinevezendố kormánybiztos feladatait illetôen. Megyei kormánybiztosoknak azokat a személyeket akarták kinevezni, akik az új megyék VB elnökei lesznek. Múködésüket a területrendezésról szóló törvény elfogadása után kezdték volna meg és az új VB-k megválasztásáig, 1957. január 6-ig tevékenykedtek volna.

Szeptember elsố napjaitól kezdve Budapest rendezésének kérdései szerepelnek a Területszervezési Kormánybizottság napirendjén. A területszervezés legnagyobb nehézségét abban látják, hogy az 1950-es rendezéskor az osztályszempontok kerültek túlhangsúlyozásra (Halász 1949), másrészt az akkor Budapesthez került fal vak minden tekintetben élvezik a fóváros által nyújtott elônyöket. A rendezést azzal is alá kívánták támasztani, hogy összehasonlították Budapest közigazgatását Moszkváéval és megállapították, hogy Budapest közigazgatása elaprózott és drága. Moszkva sokkal nagyobb és népesebb, és ott csak 23 kerület van, egy-egy kerület lakossága meghaladja a 200 ezer fốt.

A közigazgatás racionalizálása érdekében egyrészt le kell választani a korábban Budapesthez csatolt falvak egy részét, másrészt a megmaradó kerületeket össze kell vonni. A leválasztásokkal (Sashalom, Rákosszentmihály, Mátyásföld, Cinkota, Rákosliget, Rákoscsaba, Rákoshegy, Rákoskeresztúr, Pestimre, Soroksár, Budatétény, Nagytétény, Hidegkút, Békásmegyer) a fôváros területe 52.120 hektárról 33.680 hektárral csökkenne, ugyanakkor népessége 1.751.000-ról csak 1.594.200 fóre. A kerületek összevonására 13-as és 14-es a alternatívát dolgoznak ki. A belsố kerületek lélekszáma 200 ezer fö körül, a külsố kerületeké 50 ezer, távlatilag 100 ezer fố körül alakulna.

Gond van az elcsatolásra ítélt területek közigazgatási beosztásának kialakításával. Egy részükbôl négy járási jogú várost alakítanának ki, hármat pedig önálló községgé nyilvánítanának és a budai járásba osztanák be ốket. Megfogalmazzák, hogy , ,... ellátás, kommunális szolgáltatások (tarifa), közlekedés terén ugyanazt kell biztosítani a jövốben is a lecsatolandó területek lakosainak, mint Budapest lakosainak".

A közigazgatási átszervezés lehetốsége Budapesten is ellenállást váltott ki. Az összevonásra ítélt kerületek apparátusa nem értett egyet az összevonási elképzelésekkel. Budapest XVII. kerülete emlékiratot intézett a kormánybizottsághoz, amelyben idézte az 1949-1950-es rendezés 
Hajdú Zoltán: Az 1956-os közigazgatási területbeosztási reformterv földrajzi kérdései.

Tér és Társadalom, 3. 1989. 4. 43-61. p.

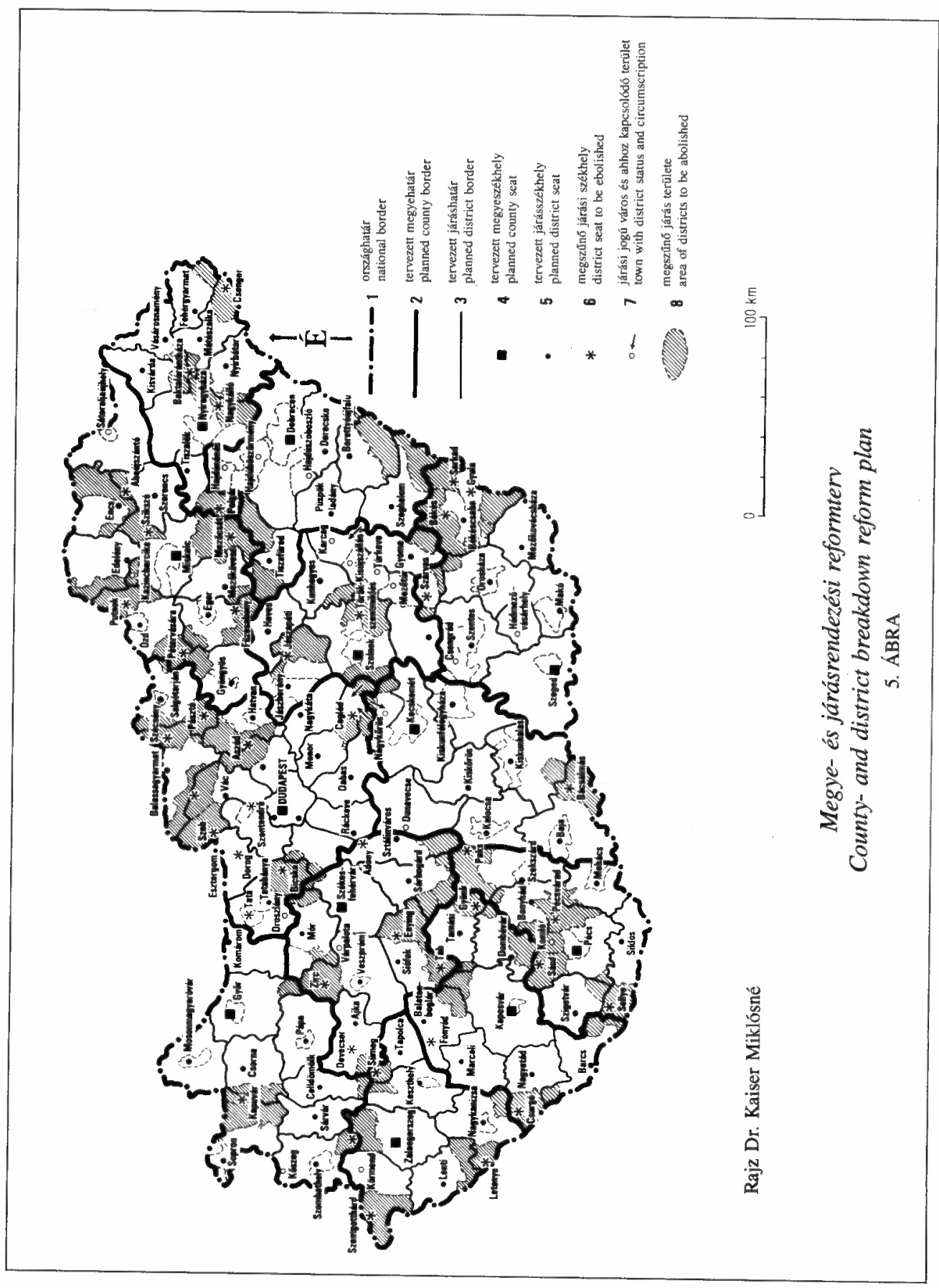


ideológiai és osztálytartalmát, és tiltakoztak az elcsatolás ellen: , Ưgy érezzük, hogy a szocialista törvényesség betartásához az is hozzátartozik, hogy mielốtt egy ilyen fontos területrendezésre kerülne sor, a lakosság véleményét figyelembe vegyék...”. Érveiket összegezve: „,Demokrácia egyenlố a népakarattal. 42.000 ember nevében akarjuk, hogy kerületünk továbbra is a Fốváros egyik kerülete legyen!"'18.

A Fớvárosi Tanács erởteljesen szorgalmazta a falusias jellegú területek lecsatolását. Ezeket a területeket perspektivikusan sem lehet a fốváros szintjére felhozni. Ugyanakkor kategórikusan igényelték:"Szüksséges, hogy a Fớvárosi Tanácsnak a városkörnyékre telepítési, közlekedési, közmưfejlesztési, egészségügyi és mezõgazdasági vonatkozásban olyan hatásköre legyen, amely biztosítja a fôváros lakosságának érdekeit. E kérdés részleteit a Fôvárosi Tanács és a Pest Megyei Tanács két hónapon belül kidolgozza".

A fốvárosi területrendezés ügye is vitákat váltott ki a kormánybizottság ülésein. $\mathrm{E}$ kérdésben kikérték Harrer Ferenc véleményét is. Apró Antal feljegyzéseiból úgy tủnik, hogy az adott körülmények között Harrer az elcsatolás mellett foglalt állást, ezzel mintegy szembekerülve korábbi évtizedes törekvéseivel. A tárgyalásokés egyeztetések végén a 14 kerület mellett foglaltak állást. A Fớvárosi Tanács ragaszkodott a falusias jellegũ települések lecsatolásához, egyedül Pestimrét volt hajlandó ,visszavenni", s fenntartotta igényét a városkörnyéki terület ügyeibe történơ , ,beleszólásra”, de , ,ezt a kérdést nem egymás hatáskörébe való beavatkozással, hanem közös munkával" kívánták rendezni.

A Területszervezési Kormánybizottság feladatköre kibő́vült, amikor a Minisztertanács 3541/1956. sz. határozatával megbízta a kormánybizottságot a hatáskörök rendezésével is. Beér János vezetésével új albizottság alakult. A Hatásköri Albizottság megkezdte a tanácsi hatáskörök áttekintését, de hamarosan nyilvánvalóvá vált, hogy a tanácsi hatáskörök csak akkor dolgozhatók át következetesen, ha az államigazgatás más területein is sor kerül a hatáskörök rendezésére. A bizottság szerint át kell gondolni a központi igazgatás teljes rendszerét is a hatáskörök tisztázása érdekében, össze kell gyưjteni a teljes élỗ joganyagot.

A Hatásköri Albizottság megállapította, hogy a hatáskörök rendezése 1956. december 31-ig nem végezhetố el, az sokkal hosszabb idốt és nagyobb munkát igényel. Két lépésben kell elvégezni:

1. 1957. január 1-ével a területi reform életbelépésekor a tanácsi hatásköröket és a VB apparátusát úgy kell megkonstruálni, hogy szervezetileg és hatáskörileg tükrözódjenek azok az intézkedések, amelyeket a MT, ill. a minisztériumok 1956. október 15-ig hoztak.

2. A teljes rendezést 1957. december 31-ig kell végrehajtani. A Hatásköri Albizottság szükségesnek ítélte a községi tanácsok helyzetének áttekintését is, és a tanácsi munka színvonalának emelését.

\section{A területrendezési terv sorsa}

A területrendezési terv, ha néha kapkodva is, kemény viták és az érzelmeket sem nélkülözổ érdekellentétek között elkészült (5. ábra, 2. táblázat). A közremúkööó tudományos kutatók, egyetemi oktatók , ,hozták" azt a szakmai ismeretet, amit a magyar tudomány az adott idôszakban nyújtani tudott. Ez korántsem volt abszolút tudományos alap, de biztosította a viszonylag széles szakmai hátteret. 
2. táblázat

A tervezett megyék fontosabb igazgatási adatai

\begin{tabular}{|c|c|c|c|c|c|}
\hline Megye & $\begin{array}{c}\text { Népesség } \\
1949 . \\
\text { jan. } 1 .\end{array}$ & $\begin{array}{c}\text { Terület } \\
\text { kh(ezer) } \\
1956 .\end{array}$ & $\begin{array}{c}\text { Járások } \\
\text { száma } \\
\text { jan. } 1 .\end{array}$ & $\begin{array}{l}\text { Városok } \\
\text { száma }\end{array}$ & $\begin{array}{c}\text { Községek } \\
\text { száma }\end{array}$ \\
\hline Baranya-Tolna & 386 & 988 & 6 & 3 & 355 \\
\hline Bács-Kiskun & 618 & 1507 & 7 & 6 & 109 \\
\hline Békés-Csongrád & 692 & 1371 & 6 & 8 & 117 \\
\hline Borsod-Heves & 722 & 1615 & 9 & 5 & 436 \\
\hline Fejêr-Veszprém & 501 & 1323 & 7 & 4 & 237 \\
\hline Gyổr-Vas & 718 & 1455 & 9 & 7 & 418 \\
\hline Hajdú & 580 & 1322 & 6 & 3 & 101 \\
\hline Pest & 1246 & 1895 & 13 & 15 & 387 \\
\hline Somogy & 427 & 1222 & 7 & 1 & 280 \\
\hline Szabolcs & 572 & 1076 & 7 & 1 & 237 \\
\hline Szolnok & 560 & 1231 & 6 & 7 & 93 \\
\hline Zala & 446 & 1024 & 6 & 3 & 428 \\
\hline Budapest & 1476 & 63 & & & \\
\hline Debrecen & 111 & 78 & & & \\
\hline Miskolc & 109 & 39 & & & \\
\hline Pécs & 88 & 25 & & & \\
\hline Szeged & 86 & 19 & & & \\
\hline Összesen & 9205 & 16166 & 89 & 68 & 3199 \\
\hline
\end{tabular}

A kidolgozott területrendezési terv most már a politikai szféra döntésmechanizmusának a körébe került. A politikai vezetésen belül eltérôen itélték meg a területi reform életbeléptetésének lehetổségeit, ill. szükségességét. 1956október elején Hegedüs András és Kádár János aggodalmukat fejezték ki, fenntartásaikat hangsúlyozták. Apró Antal kitartott a reform bevezetésének szükségessége mellett, de azt is elismerte, hogy a megyei pártszervek nagy többsége nem támogatja a reform bevezetését. Fennállt annak a veszélye, hogy a megyei pártbizottságok bizonytalansága átterjed a tanácsokra és a megyei képviselốcsoportokra. A képviselốcsoportok lényegi módosítások benyújtását fontolgatták. Ezért Apró Antal maga is javasolta a korábbi PB határozatok módosítását, de ragaszkodott ahhoz, hogy egy késốbbi idốpontban, amikor az ország politikai, gazdasági életében kevesebb zavaró tényezô lesz, a reformot be kell vezetni9 ${ }^{19}$

A megromlott gazdasági és a fokozódó belpolitikai bizonytalanságot látván a politikai vezetés úgy döntött, hogy nem terjeszti az Országgyưlés elé elfogadásra a kidolgozott területi reformot. Az 1956. október 12-i közlemény tudatja, hogy ,,A Minisztertanács a következô években nem tartja célszerũnek a területátszervezés végrehajtását, mert ez megnehezítené, hogy minden erổnket a népgazdasági feladatok sikeres megoldására, a szocialista demokratizmus fejlesztésére forditsuk" 20 
A zavarodottságra jellemzõ, hogy a közlemény megjelenésekor a Szabad Nép egy cikkében még mint napirenden szereplố kérdés jelenik meg a területi reform, majd a következõ napon a Szabad Nép egy elvi jellegưnek tũnố állásfoglalást közöl, amelyben kifejtik, hogy ,,Az idei területrendezés gondolata az ország nagy demokratizálási és egyszerûsítési folyamatának jegyében született", sok tekintetben helyes és szükségszerũ próbálkozás volt, de idổ elốttinek tekinthetô, kevés volt az idõ az elókészítésére. Nem utasítja el a területrendezés szükségességét, csak komolyabb elôkészítést és fokozatosságot helyez kilátásba, ill. igényel ${ }^{21}$.

A területrendezés lekerült a napirendról, de ha figyelmesen tanulmányozzuk az 1957 utáni közigazgatási területszervezési intézkedéseket, jónéhány esetben felfedezhetổk az 1956-os reformtervekben szereplổ megoldások. A hatáskörök leadása a helyi tanácsoknak, az államigazgatási eljárásról szóló törvény pedig a reform elemeként megvalósult.

\section{Jegyzetek}

${ }^{1}$ A tanulmány levéltári forrásbázisát első́dlegesen az Ưj Magyar Központi Levéltár anyaga képezi. Apró Antal miniszterelnök-helyettes: XIX.-A-Z-gg. törzsszám. 23 d. XVI/7. tétel: Magyarország közigazgatási beosztásának átalakítására vonatkozó javaslatok, feljegyzések, jegyzókönyvek, térképek 1956. Az iratanyag rendezett, de az egyes iratoknak nincs folyó számozása. A politikai, pártpolitikai folyamatok feltárásához felhasználhattam az MSZMP KB Párttörténeti Intézete Archívumának rendelkezésemre bocsátott iratanyagát. A két levéltári forrás között jelentós átfedések vannak, hiszen Apró Antal a Területrendezési Kormánybizottság elnöke, PB tagként szinte minden fontos irat másolatát ,hivatalbol" megkapta. Az egyes forrásokra külön hivatkozom.

${ }^{2}$ PI Archívum. PB/1170. mikrofilm. Jegyzókönyv a Politikai Bizottság 1953. 1. 22-én du. 5 orakor tartott üléséról. Elôterjesztés az ország új megyei beosztásáról. PI Archívum. 276. 53/113.ö.e. térképek.

${ }^{3}$ A Magyar Dolgozók Pártja III. kongresszusának rövidített jegyzókönyve. 1954. május 24-30. Szikra, Budapest, 1954. 375 o.

4 Uo. 70 o.

Uo. 210-271.

- Vitaülés a területrendezés kérdéseiról. - Allam és Igazgatás, 1955. VII. évf. 96-101.

${ }^{7}$ Elóterjesztés a Politikai Bizottsághoz 8 járás megszüntetésére. Budapest, 1955. december 17. Új Magyar Központi Levéltár, XIX.-A-Z-gg. 23 d. XVI/7.

- Apró Antal levele Rákosi Mátyáshoz és a PB tagjaihoz. Budapest, 1956. IV. 13. Új Magyar Központi Levéltár. Uo. A levélhez Apró mellékelte a javaslattervezetet, kérte, hogy a PB tüzze napirendre a kérdést, és elvileg foglaljon állást, hogy helyes-e, idószerǘ-e egy ilyen munkát elkezdeni. Apró Antal szerint idószerú a munka, fél év alatt eló lehet készíteni és 1957. I. 1-vel be lehet vezetni a reformot.

9 PI Archívum. PB/236. 8. Mikrofilm. Jegyzókönyv a Politikai Bizottság 1956. május 4-én tartott üléséról. Javaslat a Magyar Népköztársaság megyei beosztásának ésszerũsítésćre.

10 Szabad Nép. 1956. XIV. évf. 139. sz. május 19.

11 Beér (1956/a, 1956/b), Markos (1956), Kớács - Markója (1956) cikkei, ill. ,A területrendezés alapkérdései és módszerei"' c. anyag (Kézirat, Budapest, 1956. 15 o. MTA Földrajztudományi Kutató Intézet Könyvtára, X. 3552.)

12 A nyugtalanságot érzékelve a Központi Vezetôség Titkársága már május 26-i körlevél-tájékoztatójában igyekezett megnyugtatni a kedélyeket. Közlik a megyékkel, hogy ,,.. az átszervezés csak kidolgozás alatt áll és bevezetésére 1957. január l-én kerül sor".

PI Archívum PB 236.8. mikrofilm. 81 o.

Röviden a területrendezésrôl. Pártélet. 1956. I. évf. 9. sz. 59-60.

13 A levelet és a térképmellékletet a Közigazgatási Osztály kivizsgálás és felhasználás céljából átadta Apró Antalnak. Apró Erdei Ferencnek adta ki véleményezésre, aki a javaslatot , ,a formalista gondolkodás elrémisztó példajá’-nak minősítette.

14 Szabad Nép. 1956. XIV. évf. 175. sz. június 24. A Minisztertanács az Országgyúlés elé terjeszti a területrendezési javaslatot.

is A tervezet szerint a következö járásokat alakítanák ki (zárójelben a járáshoz tartozó községek száma és ha van, a járás alá rendelt város neve): csomai (60, Kapuvár, Csorna), gyốri (52), mosonmagyarớvári (26, Mosonmagyanóvár), soproni (41), celldömölki (35, Celldömölk), körmendi (72, Körmend, Szentgotthárd), sárvári (47, Sárvár), 
szombathelyi (67, Kõszeg), lenti (76), nagykanizsai (72), zalaegerszegi (86), zalaszentgróti (48), Ajka-devecseri (45, Ajka), keszthelyi (35, Keszthely), pápai (54), tapolcai (44, Tapolca), veszprémi (59, Várpalota, Balatonfüred), dorogi (22, Esztergom), komáromi (29, Komárom), tatai (30, Tata, Oroszlány), sárbogárdi (25), székesfehérvári (50), sztálinvárosi (15), balatonboglári (32), barcsi (42), Csurgó-nagyatádi (26), kaposvári (77), marcali (32), siófoki (38, Siófok), bonyhádi (42), dombóvári (57, Dombóvár), szekszárdi (29, Paks, Szekszárd), tamási (25), mohácsi (30, Mohács), pécsi (91, Komló), siklósi (74), szigetvári (57, Szigetvár), kecskeméti (18), kiskớrösi (13), kiskunfélegyházi (10, Kiskunfélegyháza), kiskunhalasi (12, Kiskunhalas), Nagykốrös városkörnyékéhez 1 község tartozna, ceglédi (7), monori (17), dabasi (15), dél-budai (15), észak-budai (28, Szentendre), gödöllối (20, Gödöllố), nagykátai (16), pesti (16), ráckevei (16), balassagyarmati (52, Balassagyarmat), salgótarjáni (53), váci (45, Vác), bajai (24), dunavecsei-kunszentmiklósi (14), kalocsai (15, Kalocsa), egri (41), hevesi (17), gyöngyösi (28), hatvani (30), jászberényi (16, Jászberény), edelényi (64), encsi (76), mezókövesdi (28), sátoraljaújhelyi (55, Sárospatak, Sátoraljaújhely), fehérgyarmati (52), kisvárdai (40, Kisvárda), mátészalkai (31, Mátészalka), nyírbátori (23), nyíregyházi (42), vásárosnaményi (38), debreceni (18, Hajdúszoboszló), derecskei (14), hajdúsági (1, Hajdóböszörmény, Hajdúnánás), püspökladányi (9), Tiszalök-polgári (10), Karcag városkörnyéke 2 községgel, kisújszállási (7, Kisújszállás, Túrkeve), kunszentmártoni (16), mezôtúri (3, Mezớtúr, Szarvas), szolnoki (25, Törökszentmiklós), tiszafüredi (13), berettyóújfalusi (31), békéscsabai (24, Békés), Gyula városkörnyéke 1 községgel, orosházi (12, Orosháza), szeghalmi (11), szentesi (12, Csongrád, Szentes), Hódmezơvásárhely városkörnyéke 2 községból, makói (17, Makó), mezơkovácsházi (19), szegedi (28).

${ }^{16}$ Szabad Nép. 1956. XIX. évf. 204. sz. július 23.

${ }^{17}$ Szegedet megyeszékhelynek. Beadvány Apró Antalhoz. Szerzô és dátum nélkül, 9 o. Új Magyar Központi Levéltár, XIX.-A-z-gg. 23 d. XVI/7.

18 Budapest XVII. kerület lakosságának emlékirata a kerület esetleges elcsatolása ügyében. Budapest, 1956. augusztus. 6 o. Új Magyar Központi Levéltár, XIX.-A-Z-gg. 23 d. XVI/7.

19 Apró Antal levele a Politikai Bizottság tagjaihoz. Budapest, 1956. október 11. PI Archívum. 276. f. 53/308 ö.e.

20 Elóterjesztés a Minisztertanácshoz a Magyar Népköztársaság területének államigazgatási beosztásáról. 120 . + mellékletek. PI Archívum 276. f. 76/3. ö.e.

${ }^{21}$ Szabad Nép. 1956. XIV. évf. 284. sz. október 12.

\section{Irodalom}

Beér J. (1956/a) ,, A Szovjetúnió Kommunista Pártja XX. kongresszusának tanulságai és az államépítés feladatai hazánkban" Allam és Igazgatás VIII: 257-271.

Beér J. (1956/b) „,Országgyưlésünk munkájának megjavításáról” Társadalmi Szemle XI, 6-7: 11-32.

Beér J. (1962) A helyi tanácsok kialakulása és fejlódése Magyarországon 1945-1960 (Budapest: Közgazdasági és Jogi Könyvkiadó) 646 o.

Bora Gy. (1960) „,A rayonkutatás jelentốsége és problémája a magyar gazdaságföldrajzban” Földrajzi Értesitố IX, 1: 129-141.

Halász P. (1949) „Budapest fớváros új területe” Állam és Közigazgatás, I: 536-545.

Hencz A. (1973) Teruletrendezési törekvések Magyarországon (Budapest: Közgazdasági és Jogi Könyvkiadó) 678 o.

Katona Z. - Szamel L. (1949) ,A megyék új határai” Állam és Közigazgatás I: 480-489.

Kolozsváry V. - Szamel L. (1950) ,,A járások területének rendezése” Allam és Közigazgatás II: 451-465.

Kovács I. - Markója I. (1956) ,,A bürokrácia ellen - az államigazgatás munkájának megjavításáért” Társadalmi Szemle XI, 9: 12-32.

Markos Gy. (1956) ,,A területi tervezés alapelvei és feladatai” Természet és Társadalom CXV: 341-344.

Markos Gy. (1962) Magyarország gazdasági földrajza (Budapest: Közgazdasági és Jogi Könyvkiadó) 583 o.

Szabó B. (1986) Az , ötvenes évek" (Budapest: Kossuth Könyvkiadó) 319 o. 
Tér és Társadalom 3. $\quad 1989$ • 4: 43-61.

\section{THE SPATIAL ADMINISTRATION REFORM CONCEPT OF 1956: Geographical Aspects}

\section{ZOLTÁN HAJDÚ}

The case of reforming the historical spatial breakdown of administration has been raised in Hungary as a scientific, as well an actual political, question from the 1870 s. The post-1945 period, similarly to previous ones, produced a large number of administration reform concepts, but when the administration reform was actually introduced following the communist take-over in 1949, spatial stability, rather peculiarly, was given a high priority and the radical spatial reform was, in fact, postponed.

A radical plan of establishing a spatial structure that would meet the needs of socialist development was formulated as soon as 1953 but due to the evolving political crisis it was struck off the agenda.

A period of corrections, full of contradictions itself, started in Hungarian political development in the summer of 1954 when a critical evaluation of existing structures was begun. The whole set of problems related to administration was reviewed within this context.

Preparations for reforming the spatial breakdown of administration began in the automn of 1955. At the beginning, only the most restricted circle of the central party apparatus, then the state administration, and finally the representatives of science were involved in this job.

The author provides a detailed analysis of the historical process of the formation of the political and scientific components of the spatial reform concept and the transformation of local ideas.

Central spatial reform plans came across strong oppositions of county party- and council administrations; some counties responded with counter-concepts that was inconceivable earlier. The situation got particularly hot in Csongrád, Vas and Veszprém counties.

The intention to reduce the area of Greater-Budapest created by the 1949 reform represented a special political problem. The leaders and the population of the settlements sanctioned for being detached condemned this intention extremely bitterly, they did not wish to become again 'villagers' from 'capital-dwellers'.

As a resul of the deepening internal political crisis, from the summer of 1956, the possibility and the necessity of putting the reform into practice was debated even within the party leadership. At the beginning of October 1956, following sharp debates, the party leaders decided not to introduce the reform plan elaborated for approval to the Parliament, its realization would be postponed.

The insurrection of 1956, then its suppression, created a new situation. The problems and tasks of the so-called consolidation came to the front, that needed stable administration organization and spatial breakdown.

From the beginning of the 1960 s, some elements of the reform plan of 1956 were put into practice while some others got off the agenda definitely.

Transl. E. Daróczi 
Tér és Társadalom 3. évf. 1989/4. 62. p.

62

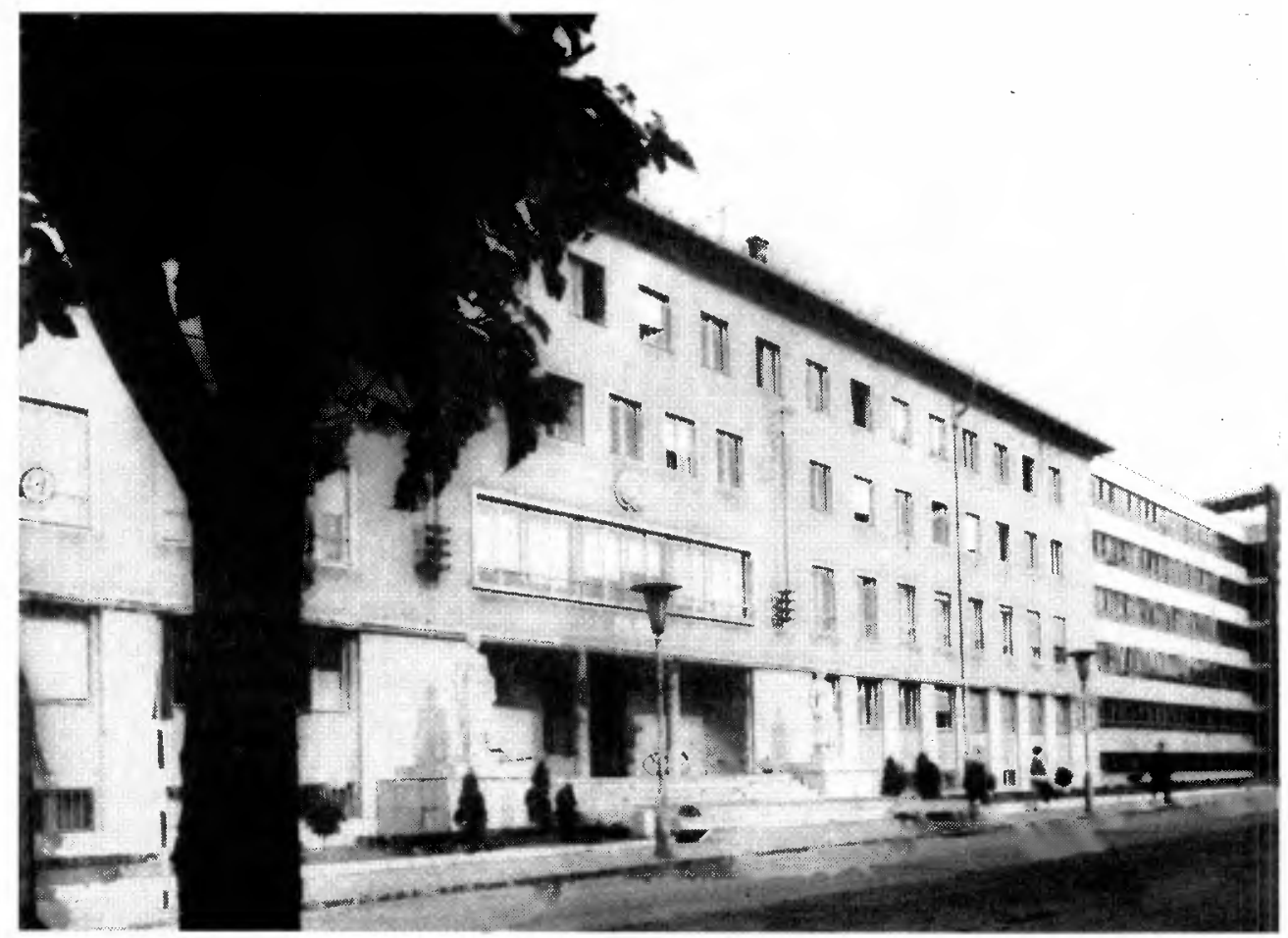

Zalaegerszeg, Megyei Tanács, mellette a megyei Tervezố Iroda székháza 1967 Foto Vidovics István MTI 